\title{
Coordinating abilities: recognition of a state of development of 11-13 years old boys
}

\author{
Ivashchenko O.V. ${ }^{1 A B C D E}$, Khudolii O.M. ${ }^{A A B C D E}$, Iermakov S.S. ${ }^{2 A B C D E}$, Prykhodko V.V. ${ }^{3 A B C D E}$ \\ ${ }^{1}$ Faculty of Physical Education and Sports, H.S. Skovoroda Kharkiv National Pedagogical University, Ukraine \\ ${ }^{2}$ Department of Tourism and Recreation, Gdansk University of Physical Education and Sport, Poland \\ ${ }^{3}$ Start-School, Kharkiv, Ukraine
}

Authors' Contribution: A - Study design; B - Data collection; C - Statistical analysis; D - Manuscript Preparation; E - Funds Collection.

\begin{abstract}
Purpose: $\quad$ To determine the possibility of recognizing the state of development of coordination abilities in boys 11-13 years old based on the methodology of multidimensional statistics.

Material: $\quad$ The study involved boys: $11(n=21), 12(n=20), 13(n=19)$ years. It was used 14 tests.

Results: In the recognition of the state of development of coordination abilities in boys of 11-13 years old, the most important are the results in the tests: №2 "Standing long jump (cm)" (0.633); №12 "Rhythmic hand tapping" (-0.493); №15 “Tossing a ring over a peg" (-0.347). The enumerated tests characterize speed-power abilities, coordination of movements by hands and spatial precision of throws. In recognition of the state of development of coordination abilities in boys of 12-13 years old, the most important are the results in the tests: №12 "Rhythmic hand tapping" (0.691); №2 "Standing long jump (cm)" (0,387); №1 "30 m running (s)" $(-0,356)$. The enumerated tests characterize the coordination of movements by the hands, speed-strength abilities and speed.

Conclusions: Discriminant analysis allowed to determine: informative indicators for the walkthrough of the development of coordination abilities in boys of 11-13 years old; to answer such question as how significantly distinguished the state of development of coordination abilities in boys of 11-13 years old; which motor tests most significantly affect the differentiation of classes; to which class the object belongs to based on the values of discriminant variables.

Keywords: discriminant analysis, walkthrough, motor tests, boys.
\end{abstract}

\section{Introduction}

In the process of physical education of schoolchildren the tasks of optimizing the physical development of the child are solved [1, 2], improvement of motor abilities, strengthening and health protection $[3,4]$.

Based on numerous studies, conclusions are drawn:

- the need for a comprehensive development of strength, coordination, endurance and flexibility in children [5, 6];

- the importance of developing coordination of movements in the process of physical education of schoolchildren [3, 7];

- on the relationship of anthropometric, motor and cognitive abilities in children [8, 9];

- the association of the body mass index and subcutaneous adipose tissue with the manifestation of coordination of movements in children 11-14 years [10];

- on the influence of visual perception on the coordination of movements of various parts of the body of children [11, 12];

- on the effect of loads on the plasticity of motor skills in schoolchildren [13, 14].

In other works, attention was focused on clarification of the concept of coordination abilities [2, 5], as well as on the definition of their structure $[15,16]$.

It is established that in the motor readiness of children and adolescents, coordination abilities occupy a leading

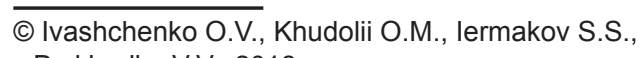

Prykhodko V.V., 2018

doi:10.15561/18189172.2018.0204 place [17, 18]. Multidimensional methods of mathematical statistics are used to study the structure of motor readiness of schoolchildren: factor and discriminant analysis [3, 19]. The use of factor analysis allowed to establish the structure of development of coordination abilities in 1113 years old boys and girls [20, 21]. However, in available literature there is not enough data on the peculiarities of the dynamics of development of coordination abilities in high school students.

Thus, the study of the peculiarities of the dynamics of development of coordination abilities on the basis of recognition of their state of development in middle school boys is relevant.

The purpose of the study is to determine the possibility of recognizing the state of development of coordination abilities in 11-13 years old boys based on the methodology of multidimensional statistics.

\section{Materials and methods}

Study participants. The study involved boys: 11 (n = 21), $12(\mathrm{n}=20), 13(\mathrm{n}=19)$ years old.

The study protocol was approved by the Ethical Committee of H. S. Skovoroda Kharkiv National Pedagogical University. In addition, the children and their parents or legal guardians were fully informed about all the features of the study, and a signed informed-consent document was obtained from all the parents.

Study organization. The study used the following methods: analysis and collation of scientific and 
methodological literature, general scientific methods of theoretical level, such as analogy, analysis, synthesis, abstraction, induction, as well as general scientific methods of empirical level: observation, testing, experiment.

Testing procedure. The testing program included wellknown tests [3, 5, 22]. To evaluate motor preparedness, the study recorded the results of motor tests, body height and weight [21]:

- Test 1 "30 m running (s)";

- Test 2 "Standing long jump (cm)";

- Test 3 "Six standing accuracy ball handlings to a partner from a $7 \mathrm{~m}$ distance using one of the techniques learned".

- Test 4 "Pull-ups (number of times)";

- Test 5 "Sit-ups in 30 seconds";

- Test 6 "Evaluation of the sense of movement speed in sprinting";

- $\quad$ Test 7 "Evaluation of the ability to differentiate movement speed (reproduction accuracy of running speed at $80 \%$ intensity of maximum)";

- $\quad$ Test 8 "Evaluation of the ability to differentiate movement speed (reproduction accuracy of running speed at 90\% intensity of maximum)";

- Test 9 "Static equilibrium evaluation by E. Ya. Bondarevsky's method";

- Test 10 "Evaluation of dynamic equilibrium by the BESS method";

- Test 11 "Evaluation of the ability for vestibular (statokinetic) stability. Running with turns";

- Test 12 "Rhythmic hand tapping";

- Test 13 "Rhythmic movements of upper and lower limbs";

- Test 14 "Shuttle run $(4 \times 9 \mathrm{~m})$ ";

- Test 15 "Tossing a ring over a peg".

Pedagogical testing was conducted to determine the possibility of recognizing the state of development of coordination abilities in boys aged 11-13 years based on the methodology of multidimensional statistics.

Statistical analysis.

In discriminant analysis we formed prognostic model of belonging to group. This model builds discriminant function (or if the quantity of groups is more than two - a set of discriminant functions) in the form of linear combination of variables-predictors that ensures the best groups' division. These functions are built by a set of observations, for which their belonging to groups is known. Further, these functions can be used for new observations with known values of variables- predictors and unknown belonging to group.

For every variable we calculated the following: mean values, standard deviations, single - factorial dispersion analysis for every variable (Box's $\mathrm{M}$ test, in-group correlation matrix, in-group covariance matrix, covariance matrixes for separate groups, general covariance matrix). For every canonic discriminant function we calculated: eigenvalue, dispersion percentage, canonic correlation, Wilks' Lambda, Chi-square. For every step we calculated: priory probabilities, Fisher function's coefficients, non-standardized coefficients of function, Wilks’ Lambda for every canonic function.

\section{Results}

The tables show the results of discriminant analysis, which allows to recognize the state of development of coordination of movements in boys of 11-13 years.

The first canonical function explains the variation of the results by $77.2 \%$, the second - by $22.8 \%$. This indicates their informativity (Table 1). The coefficients of canonical correlation indicate the prognosticity of the first and second functions.

Table 2 shows the analysis of canonical functions. The first line contains the value $\lambda=0.099(p=0.001)$ for the entire set of canonical functions. The second line contains data after the exclusion of the first function $(\lambda=0,472$; $\mathrm{p}=0,002)$. The first and second functions have a high discriminative ability and meaning in the interpretation of the general population.

Table 3 shows the normalized coefficients of the canonical discriminant function, which allow us to determine the ratio of the contribution of variables to the result of a function. The greatest contribution to the first canonical function is the variables number 2, 16, 12, 15 : the larger the values of these variables, the greater the value of the function. With the greatest contribution to the second canonical function, the variables are number 12, 2 , 1: the larger the values of these variables, the greater the value of the function.

In identifying the state of development of coordination

Table 1. Summary of Canonical Discriminant Functions. Eigenvalues. Boys of 11-13 years

\begin{tabular}{lllll}
\hline Function & Eigenvalue & \% of Variance & Cumulative \% & Canonical Correlation \\
\hline 1 & $3,789^{\mathrm{a}}$ & 77,2 & 77,2 &, 889 \\
2 & $1,120^{\mathrm{a}}$ & 22,8 & 100,0 &, 727 \\
\hline
\end{tabular}

Table 2. Canonical discriminatory functions. Wilks' Lambda. Boys of 11-13 years

\begin{tabular}{lllll}
\hline Test of Function(s) & Wilks' Lambda & Chi-square & df & Sig. \\
\hline 1 through 2 &, 099 & 113,563 & 34 &, 000 \\
2 &, 472 & 36,817 & 16 &, 002 \\
\hline
\end{tabular}


abilities in boys of 11-13 years old, the most important are the results in tests: №2 "Standing long jump (cm)” (0.633), №12 "Rhythmic hand tapping” (-0.493), №15 “Tossing a ring over a peg" (-0.347). The named tests characterize speed-power abilities, coordination of movements by hands and spatial precision of throws.

In the recognition of the state of development of coordination abilities in boys of 12-13 years old the most important are the results in tests: № 12 "Rhythmic hand tapping” (0.691), №2 “Standing long jump (cm)” (0.377), test №1 “30 m running (s)” (-0.356). The enumerated tests characterize the coordination of movements by the hands, speed-strength abilities and speed.

Table 4 shows the structural coefficients of the first and second canonical discriminant functions, which are coefficients of the correlation of variables with a function. Thus, the first canonical discriminant function is most closely connected with the results of tests №2, 17, 16, 9, 14: hence, the significant difference between boys 11, 12 and 13 years is observed in the level of development of high-speed force, coordination of movements and anthropometric data. The structural coefficients of the second canonical discriminant function indicate that the function is most closely related to the variables №12, 13, 15, 3: hence, the significant difference between the boys of 12 and 13 years is observed in coordinating the movements of the hands and the accuracy of the throws.

Table 5 shows the results of classification of groups, $93.3 \%$ of the output grouped observations are categorized correctly. Thus, a canonical discriminatory function can be used to recognize the state of coordination of movements in boys aged 11-13 years.

\section{Discussion}

The presented results indicate that discriminant analysis allows to recognize the state of development of coordination abilities in boys aged 11-13 years on the results of testing. Our research complements data on the use of discriminant function in the classification of students by motor activity [23, 24]. According to our results, there is a high discriminant and prognostic ability of the received functions in assessing the motor readiness of children and adolescents. Similar results were obtained in Geoffrey D.B. et al [25], Ivashchenko et al. [26].

For the practical application of the results of discriminant analysis, the coefficients of the canonical discriminant function are used (Table 6). The probability of belonging to a certain case to the predicted group is calculated based on the substitution of the discriminant function of the values of the set of variables. These variables correspond to this case. Comparison of the obtained results with the size of centroids makes it possible to determine the group to which the result belongs (Table 7).

Previously, it was found that in the structure of coordination abilities of boys aged 11-13 years the most informative is vestibular stability. For pedagogical control of motor readiness of boys aged 11-13 years can be recommended: test №2 "Standing long jump (cm)”; test №9 "Static equilibrium evaluation by E. Ya. Bondarevsky's method”; test №10 "Evaluation of dynamic equilibrium by the BESS method" [27].

The results of the discriminant function allowed to determine that for recognizing the level of development of coordination abilities in boys aged 11, 12 and 13 years

Table 3. Standardized Canonical Discriminant Function Coefficients. Boys aged 11-13 years old

\begin{tabular}{|c|c|c|c|}
\hline \multirow[t]{2}{*}{ № } & \multirow[t]{2}{*}{ Test } & \multicolumn{2}{|c|}{ Function } \\
\hline & & 1 & 2 \\
\hline 1 & 30 m running $(s)$ & ,001 &,- 356 \\
\hline 2 & Standing long jump (cm) & ,633 & ,387 \\
\hline 3 & $\begin{array}{l}\text { Six standing accuracy ball handlings to a partner from a } 7 \mathrm{~m} \text { distance using one of } \\
\text { the techniques learned }\end{array}$ & $f-370$ &,- 349 \\
\hline 4 & Pull-ups (number of times) & ,240 &,- 064 \\
\hline 5 & Sit-ups in 30 seconds & ,287 &,- 090 \\
\hline 6 & Evaluation of the sense of movement speed in sprinting & ,162 & ,303 \\
\hline 7 & $\begin{array}{l}\text { Evaluation of the ability to differentiate movement speed (reproduction accuracy } \\
\text { of running speed at } 80 \% \text { intensity of maximum) }\end{array}$ &,- 074 &,- 307 \\
\hline 8 & $\begin{array}{l}\text { Evaluation of the ability to differentiate movement speed (reproduction accuracy } \\
\text { of running speed at } 90 \% \text { intensity of maximum) }\end{array}$ & ,211 &,- 001 \\
\hline 9 & Static equilibrium evaluation by E. Ya. Bondarevsky's method & 113 &,- 314 \\
\hline 10 & Evaluation of dynamic equilibrium by the BESS method &,- 290 &,- 165 \\
\hline 11 & Evaluation of the ability for vestibular (statokinetic) stability. Running with turns & ,148 & 132 \\
\hline 12 & Rhythmic hand tapping &,- 493 & 691 \\
\hline 13 & Rhythmic movements of upper and lower limbs & ,024 & ,330 \\
\hline 14 & Shuttle run $(4 \times 9 \mathrm{~m})$ &,- 301 & ,312 \\
\hline 15 & Tossing a ring over a peg &,- 347 &,- 269 \\
\hline 16 & Height (cm) & ,547 & ,210 \\
\hline 17 & Body weight $(\mathrm{kg})$ & ,226 & ,348 \\
\hline
\end{tabular}


Table 4. Structure Matrix. Boys aged 11-13 years old

\begin{tabular}{|c|c|c|c|}
\hline № & Test & $\begin{array}{l}\text { Function } \\
1\end{array}$ & 2 \\
\hline 2 & Standing long jump (cm) & ,419* & 127 \\
\hline 17 & Body weight (kg) &, $395^{*}$ & 167 \\
\hline 16 & Height $(\mathrm{cm})$ & ,378* & 196 \\
\hline 9 & Static equilibrium evaluation by E. Ya. Bondarevsky's method & ,358* &,- 156 \\
\hline 14 & Shuttle run $(4 \times 9 \mathrm{~m})$ &,$- 282^{*}$ & 200 \\
\hline 4 & Pull-ups (number of times) & $245^{*}$ &,- 004 \\
\hline 10 & Evaluation of dynamic equilibrium by the BESS method &,$- 184^{*}$ & 119 \\
\hline 8 & $\begin{array}{l}\text { Evaluation of the ability to differentiate movement speed (reproduction accuracy } \\
\text { of running speed at } 90 \% \text { intensity of maximum) }\end{array}$ & $164^{*}$ &,- 071 \\
\hline 12 & Rhythmic hand tapping &,- 266 &, $523^{*}$ \\
\hline 13 & Rhythmic movements of upper and lower limbs &,- 039 &, $313^{*}$ \\
\hline 15 & Tossing a ring over a peg & ,047 &,$- 271^{*}$ \\
\hline 3 & $\begin{array}{l}\text { Six standing accuracy ball handlings to a partner from a } 7 \mathrm{~m} \text { distance using one of } \\
\text { the techniques learned }\end{array}$ & f,- 077 &,$- 233^{*}$ \\
\hline 5 & Sit-ups in 30 seconds & 104 &,$- 203^{*}$ \\
\hline 7 & $\begin{array}{l}\text { Evaluation of the ability to differentiate movement speed (reproduction accuracy } \\
\text { of running speed at } 80 \% \text { intensity of maximum) }\end{array}$ & 077, &,$- 158^{*}$ \\
\hline 1 & 30 m running $(s)$ &,- 083 &,$- 129^{*}$ \\
\hline 6 & Evaluation of the sense of movement speed in sprinting &,- 047 &, $067^{*}$ \\
\hline 11 & Evaluation of the ability for vestibular (statokinetic) stability. Running with turns & 055 & $059^{*}$ \\
\hline
\end{tabular}

Table 5. Classification Results ${ }^{\mathrm{a}}$. Boys aged 11-13 years old

\begin{tabular}{|c|c|c|c|c|c|c|}
\hline \multirow{2}{*}{ Scale } & \multirow{2}{*}{ Age (years) } & \multirow{2}{*}{ Group } & \multicolumn{3}{|c|}{ Predicted Group Membership } & \multirow{2}{*}{ Total } \\
\hline & & & 1,00 & 2,00 & 3,00 & \\
\hline \multirow{6}{*}{ Original } & \multirow{4}{*}{ Count } & 5,00 & 21 & 0 & 0 & 21 \\
\hline & & 6,00 & 2 & 17 & 1 & 20 \\
\hline & & 7,00 & 0 & 1 & 18 & 19 \\
\hline & & 5,00 & 100,0 & 0 & 0 & 100,0 \\
\hline & \multirow{2}{*}{$\%$} & 6,00 & 10,0 & 85,0 & 5,0 & 100,0 \\
\hline & & 7,00 & 0 & 5,3 & 94,7 & 100,0 \\
\hline
\end{tabular}

$93,3 \%$ of original grouped cases correctly classified.

Table 6. Canonical Discriminant Function Coefficients. Boys aged 11-13 years old

\begin{tabular}{|c|c|c|c|}
\hline \multirow{2}{*}{ № } & \multirow{2}{*}{ Test } & \multicolumn{2}{|l|}{ Function } \\
\hline & & 1 & 2 \\
\hline 1 & 30 m running (s) & ,002 &,- 976 \\
\hline 2 & Standing long jump (cm) & ,057 & ,035 \\
\hline 3 & $\begin{array}{l}\text { Six standing accuracy ball handlings to a partner from a } 7 \mathrm{~m} \text { distance using one of } \\
\text { the techniques learned }\end{array}$ &,- 335 &,- 317 \\
\hline 4 & Pull-ups (number of times) & ,211 &,- 056 \\
\hline 5 & Sit-ups in 30 seconds & ,057 &,- 018 \\
\hline 6 & Evaluation of the sense of movement speed in sprinting & 1,237 & 2,316 \\
\hline 7 & $\begin{array}{l}\text { Evaluation of the ability to differentiate movement speed (reproduction accuracy } \\
\text { of running speed at } 80 \% \text { intensity of maximum) }\end{array}$ &,- 619 & $-2,555$ \\
\hline 8 & $\begin{array}{l}\text { Evaluation of the ability to differentiate movement speed (reproduction accuracy } \\
\text { of running speed at } 90 \% \text { intensity of maximum) }\end{array}$ & 2,290 &,- 006 \\
\hline 9 & Static equilibrium evaluation by E. Ya. Bondarevsky's method & ,011 &,- 030 \\
\hline 10 & Evaluation of dynamic equilibrium by the BESS method &,- 045 &,- 026 \\
\hline 11 & Evaluation of the ability for vestibular (statokinetic) stability. Running with turns & 143 & 128 \\
\hline 12 & Rhythmic hand tapping &,- 351 & 493 \\
\hline 13 & Rhythmic movements of upper and lower limbs & ,023 & 307 \\
\hline 14 & Shuttle run $(4 \times 9 \mathrm{~m})$ &,- 333 & ,346 \\
\hline 15 & Tossing a ring over a peg &,- 139 &,- 108 \\
\hline 16 & Height (cm) & ,070 & ,027 \\
\hline 17 & Body weight (kg) &, 026 & ,040 \\
\hline & (Constant) & $-13,658$ & $-8,482$ \\
\hline
\end{tabular}


Table 7. Functions at Group Centroids. Boys aged 11-13 years old

\begin{tabular}{lll}
\hline Group & Function & \\
\hline 5 & $\mathbf{1}$ & $\mathbf{2}$ \\
6 & $-2,061$ &,- 848 \\
7 &,- 274 & 1,451 \\
\hline
\end{tabular}

can be used: test №9 "Static equilibrium evaluation by E. Ya. Bondarevsky’s method"; test № 14 "Shuttle run (4x9 m)". These tests characterize vestibular stability and overall coordination of movements. For recognition of the state of development of coordination abilities in boys 12 and 13 years can be used tests: № 12 "Rhythmic hand tapping”; №13 "Rhythmic movements of the upper and lower limbs"; №15 “Tossing a ring over a peg”. These tests characterize the coordination of movements of different parts of the body and the accuracy of throws. These data supplement the results of Agricola et al. [11] and PalomoNieto et al. [12] on the importance of coordinating movements of various parts of the body in assessing the coordination abilities of children and adolescents. The given data confirm conclusions of Ivashchenko O. [3]: for the estimation of the current state of motor readiness, a factor analysis is used; to assess the dynamics of the state in the age range, a discriminant analysis is used, which makes it possible to determine informative indices for the cross-sectional control of motor readiness.

The above data supplements the results of the study of the peculiarities of motor readiness of middle school students [15, 28].

\section{Conclusions}

Discriminant analysis allowed to determine: informative indicators for the end control of the development of coordination abilities in boys aged 1113 years; to answer the question as to how significantly the state of development of coordination abilities in boys of 11, 12 and 13 years old; which motor tests most significantly affect the differentiation of classes; to which class the object belongs to based on the values of discriminant variables.

For the recognition of the level of development of coordination abilities in boys 11, 12 and 13 years can be used: test №9 "Static equilibrium evaluation by E. Ya. Bondarevsky's method"; test № 14 "Shuttle run (4x9 m)". These tests characterize vestibular stability and overall coordination of movements.

For recognition of the state of development of coordination abilities in boys of 12 and 13 years old can be used tests: № 12 "Rhythmic hand tapping”; №13 "Rhythmic movements of the upper and lower limbs"; №15 "Tossing a ring over a peg”. These tests characterize the coordination of movements of different parts of the body and the accuracy of throws.

The prospect of further exploration is the study of methodological approaches to programming of the development of coordination abilities in schoolchildren of secondary school age.

\section{Acknowledgment}

The research was carried out according to the theme 13.04 "Modelling of the learning process and development of motor abilities in children and adolescents" (20132014) (state registration number 0113U002102).

\section{Conflict of Interest}

The authors state that there is no conflict of interest.

\section{References}

1. Balsevich VK. Ontokinesiology of man. Moscow: Theory and practice of physical culture; 2000. (in Russian).

2. Ilyin EP. Psychomotor organization of man: training. for universities. St. Petersburg: Peter; 2003. (in Russian)

3. Ivashchenko OV. Modelling of physical education students. Kharkiv: OVS; 2016. (in Ukrainian)

4. Emeljanovas A, Mieziene B, Putriute V. The Relationship Between Physical Activity and Content of the Physical Education Classes in 11-12 Years Old Lithuanian Schoolchildren. The Pilot Study. Croatian Journal of Education-Hrvatski Casopis Za Odgoj I Obrazovanje, 2015; 17(1): 93-120.

5. Liakh VI. Driving abilities of schoolchildren: Fundamentals of theory and methods of development. Moscow: TerraSport; 2000.

6. Krutsevych TYu, Bezverkhnia HV. Recreation in the physical culture of different population groups: teaching. manual. Kiev: Olympic Literature; 2010. (in Ukrainian)

7. Ivashchenko O. Methodological Approaches to Pedagogical Control of Motor Readiness of Girls Aged 6-10. Teorîa Ta
Metodika Fìičnogo Vihovannâ, 2017; 17(3): 126-138. doi:10.17309/tmfv.2017.3.1197

8. Iadreev V, Cherkashin I, Vujkov S, Drid P. Differences in anthropometric, motoric and cognitive abilities between athletically trained and untrained girls. Biomedical Human Kinetics, 2015; 7(1): 73-77. doi:10.1515/bhk-2015-0012

9. Novak D, Podnar H, Emeljanovas A, Marttinen R. Comparison of Fitness Levels between Croatian and Lithuanian Students. Montenegrin Journal of Sports Science and Medicine, 2015; 4(1): 5-11.

10.Drid P, Vujkov S, Jaksic D, Trivic T, Marinkovic D, Bala G. Differences in Motor and Cognitive Abilities of Children Depending on Their Body Mass Index and Subcutaneous Adipose Tissue. Collegium Antropologicum, 2013; 37(2): 171-177.

11. Agricola A, Psotta R, Abdollahipour R, Nieto MP. The differences of movement between children at risk of developmental coordination disorder and those not at risk. Acta Gymnica, 2015; 45(3): 129-138. doi:10.5507/ ag.2015.007

12.Palomo-Nieto M, Psotta R, Agricola A, Abdollahipour R, 
Valtr L. The effects of various visual conditions on the gait cycle in children with different level of motor coordination - a pilot study. Ricyde-Revista Internacional De Ciencias Del Deporte, 2015; 11(42): 387-399. doi:10.5232/ ricyde2015.04207

13.Hadžić R, Bjelica D, Vujović D, Popović S. Effects of highlow aerobic program on transformation of motor skills at high school students. Sport Science, 2015; 8(1): 79-84.

14.Khudolii OM, Ivashchenko OV. Simulation of the learning process and development of motor abilities in children and adolescents. Kharkiv: OVS; 2014. (in Ukrainian)

15.Ivashchenko O, Khudolii O, Iermakov S, Lochbaum M, Cieślicka M, Zukow W, Nosko M, Yermakova T. Methodological approaches to pedagogical control of the functional and motor fitness of the girls from 7-9 grades. Journal of Physical Education and Sport, 2017; 17(1): 254261.

16.Khudolii OM, Iermakov SS, Prusik K. Classification of motor fitness of 7-9 years old boys. Journal of Physical Education and Sport, 2015; 15(2): 245-253. doi:10.7752/ jpes.2015.02038

17.Serhiienko LP, Chekmarova NH, Khadzhynov VA. Psychomotor: Monitoring and Evaluation of Development, Kharkiv: OVS; 2012. (in Ukrainian)

18.Khudolii OM. General Fundamentals of Theory and Methodology of Physical Education. Kharkiv: OVS; 2008. (in Ukrainian)

19.Lopatiev A, Ivashchenko O, Khudolii O, Pjanylo Y, Chernenko S, Yermakova T. Systemic approach and mathematical modeling in physical education and sports. Journal of Physical Education and Sport, 2017; 17 (1):146155.

20.Prykhodko VV. Comparative Analysis of Indicators of Coordination Abilities Development in 5th-7th Graders.
Teoriâ ta Metodika Fìzičnogo Vihovannâ, 2017; 17(3): 148156. doi:10.17309/tmfv.2017.3.1199

21.Ivashchenko O, Prykhodko V, Cieslicka M. Movement Coordination: Factor Structure of Development in 5th-7th Grade Girls. Teoriâ Ta Metodika Fìzičnogo Vihovannâ, 2018; 18(1): 38-49. doi:10.17309/tmfv.2018.1.05

22.Serhiienko LP. Testing of motor abilities of schoolchildren. Kiev: Olympic Literature; 2001. (in Ukrainian)

23.Gert-Jan de Bruijn, Benjamin Gardner. Active Commuting and Habit Strength: An Interactive and Discriminant Analyses Approach. American Journal of Health Promotion, 2011; 25(3): e27-e36. doi:10.4278/ajhp.090521-QUAN-170

24.Lulzim I. Discriminant analysis of morphologic and motor parameters of athlete and non athlete girl pupils of primary school on age 14 to 15 years. RIK, 2013; 40(2): 185-190.

25.Geoffrey D Broadhead, Gabie E Church. Discriminant Analysis of Gross and Fine Motor Proficiency Data. Perceptual and Motor Skills, 1982; 55(2): 547-552. doi:10.2466/pms.1982.55.2.547

26.Ivashchenko O, Abdulkhalikova T, Cieślicka M. Effectiveness of Motor Skills Development in 5th-7th Grade Girls at Different Modes of Physical Exercises. Teorìa Ta Metodika Fìzičnogo Vihovannâ, 2017; 17(4): 201-207. doi:10.17309/ tmfv.2017.4.1205

27.Prykhodko VV. The Factor Structure of Coordination Abilities Development in 5th-7th Grade Boys. Teorîa ta Metodika Fìičnogo Vihovannâ, 2017; 17(4): 191-200. doi:10.17309/tmfv.2017.4.1204

28.Khudolii OM, Prykhodko VV, Ivashchenko OV. Features of development of coordination characteristics the girls grades 5-7. Visnyk Chernihivskoho natsionalnoho pedahohichnoho universytetu. Seriia: Pedahohichni nauky. Fizychne vykhovannia ta sport, 2017; 1(147): 221-228. (in Ukrainian)

Information about the authors:

Ivashchenko O.V.; http://orcid.org/0000-0002-2708-5636; tmfv@tmfv.com.ua; Faculty of Physical Education and Sports, H.S. Skovoroda Kharkiv National Pedagogical University; Alchevskyh str. 29, Kharkiv, 61002, Ukraine.

Khudolii O.M. (Corresponding author); http://orcid.org/ 0000-0002-5605-9939; tmfv@tmfv.com.ua; Faculty of Physical Education and Sports, H.S. Skovoroda Kharkiv National Pedagogical University; Alchevskyh str. 29, Kharkiv, 61002, Ukraine.

lermakov S.S.; http://orcid.org/0000-0002-5039-4517; sportart@gmail.com; Department of Tourism and Recreation, Gdansk University of Physical Education and Sport; Kazimierza Górskiego 1, 80-336 Gdańsk, Poland.

Prykhodko V.V.; http://orcid.org/0000-0002-9095-0573; vladimir3733614@gmail.com; Start-School, Kharkiv; Sadovaya st., 20, Kharkiv, 61000, Ukraine.

Cite this article as: Ivashchenko O.V., Khudolii O.M., Iermakov SS, Prykhodko VV. Coordinating abilities: recognition of a state of development of 11-13 years old boys. Pedagogics, psychology, medical-biological problems of physical training and sports, 2018;22(2):86-91. doi:10.15561/18189172.2018.0204

The electronic version of this article is the complete one and can be found online at: http://www.sportpedagogy.org.ua/index.php/PPS/issue/archive

This is an Open Access article distributed under the terms of the Creative Commons Attribution License, which permits unrestricted use, distribution, and reproduction in any medium, provided the original work is properly cited (http://creativecommons.org/licenses/by/4.0/deed.en).

Received: 16.12 .2017

Accepted: 08.01.2018; Published: 30.04.2018 